\title{
Optic neuritis as the ocular manifestation of dengue infection: a case report
}

Indra Tri Mahayana ${ }^{1}$, Andreas Surya Anugrah $^{1}$, Ika Kartika ${ }^{1}$, Natalia Christina Angsana ${ }^{2}$, Tatang Talka Gani ${ }^{1}$

${ }^{1}$ Department of Ophthalmology, Faculty of Medicine, Public Health, and Nursing, Universitas Gadjah Mada, Yogyakarta, Indonesia; ${ }^{2}$ Faculty of Medicine, Public Health, and Nursing, Universitas Gadjah Mada, Yogyakarta, Indonesia

\section{Abstract}

Optic neuritis is characterized by decreased vision, impaired colour perception, relative afferent pupillary defects, and scotoma. Optic neuritis following dengue infection is rare and might be underdiagnosed. The pathophysiology of optic neuritis after dengue infection is still unclear and there are only a few reports. We report a case of bilateral simultaneous optic neuritis in a young female adult following dengue haemorrhagic fever. On presentation, she complained of blurred vision, pain around the eyes, central scotoma, and progressively worsening visual acuity to no perception of light in both eyes. The next day, laboratory examination

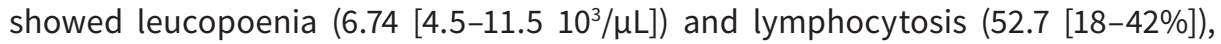
suggesting viral infection with positive anti-dengue IgM and IgG. The patient received intravenous pulse steroid therapy according to the Optic Neuritis Treatment Trial. At 3 months follow-up, best corrected visual acuity improved to $6 / 6$, with pale optic discs but normal perimetry. Although complications of dengue fever in the eye are rare, early recognition must be established to prevent permanent vision loss.

Keywords: dengue haemorrhagic fever, optic neuritis, optic neuropathy

Correspondence: Indra Tri Mahayana, MD, PhD, Department of Ophthalmology, Faculty of Medicine Public Health and Nursing, Universitas Gadjah Mada, Farmako, Sekip Utara, Yogyakarta, Indonesia.

E-mail: indra.tri.m@mail.ugm.ac.id 


\section{Abstrak}

Neuritis optik dicirikan oleh kekurangan ketajaman penglihatan, persepsi warna yang terganggu, kecacatan pupil aferen relatif, dan skotoma. Neuritis optik berikutan jangkitan denggi jarang berlaku dan mungkin tidak didiagnosis. Patofisiologi neuritis optik selepas jangkitan denggi masih belum jelas dan hanya ada beberapa laporan. Kami melaporkan kes neuritis optik serentak kedua belah mata pada seorang wanita dewasa berikutan demam denggi. Ketika ditemui, beliau mengadu penglihatannya kabur, sakit di sekitar mata, skotoma pusat, dan ketajaman penglihatannya semakin teruk sehingga tidak ada persepsi cahaya pada kedua mata. Pada keesokan harinya, pemeriksaan makmal menunjukkan leukopenia $(6,74$ [4,5-11,5 $103 / \mu \mathrm{L}])$ dan limfositosis (52,7 [18-42\%]), menunjukkan jangkitan virus dengan IgM dan IgG anti-denggi positif. Pesakit menerima terapi steroid secara intravena mengikut Kajian Rawatan Neuritis Optik. Pada tarikh susulan 3 bulan, ketajaman visual terbaik meningkat kepada 6/6, dengan cakera optik kelihatan pucat tetapi uijian perimetri adalah normal. Walaupun komplikasi demam denggi di mata jarang terjadi, pengenalan awal mesti dilakukan untuk mencegah kehilangan penglihatan kekal.

Kata kunci: demam berdarah denggi, neuritis optik, neuropati optik

\section{Introduction}

Optic neuritis following dengue infection, or parainfectious neuritis, is still very rare or might be underdiagnosed. Dengue infection is a very common infection in tropical and subtropical areas with a geographical coverage of more than 100 countries worldwide. ${ }^{1}$ However, there are very few reports regarding this condition. We are reporting a case of bilateral optic neuritis after dengue infection in a 20 -year-old patient with bilateral vision loss. At 3 months of follow-up, there was sharp improvement in visual acuity (VA) to $6 / 6$ after steroid administration.

\section{Case report}

\section{Patient characteristics}

A 20-year-old female patient presented with acute vision loss in both eyes. One week before that, she had been hospitalized for 5 days at a local hospital because of dengue haemorrhagic fever with a platelet count of $69,000 / \mu \mathrm{L}$. After 5 days of inpatient treatment, she had been discharged in good condition. Two days after discharge, the patient began to develop blurry vision in both eyes with associated pain around the eyes. On the following day, she felt her central vision decrease in her right eye, which was followed by the left eye. 


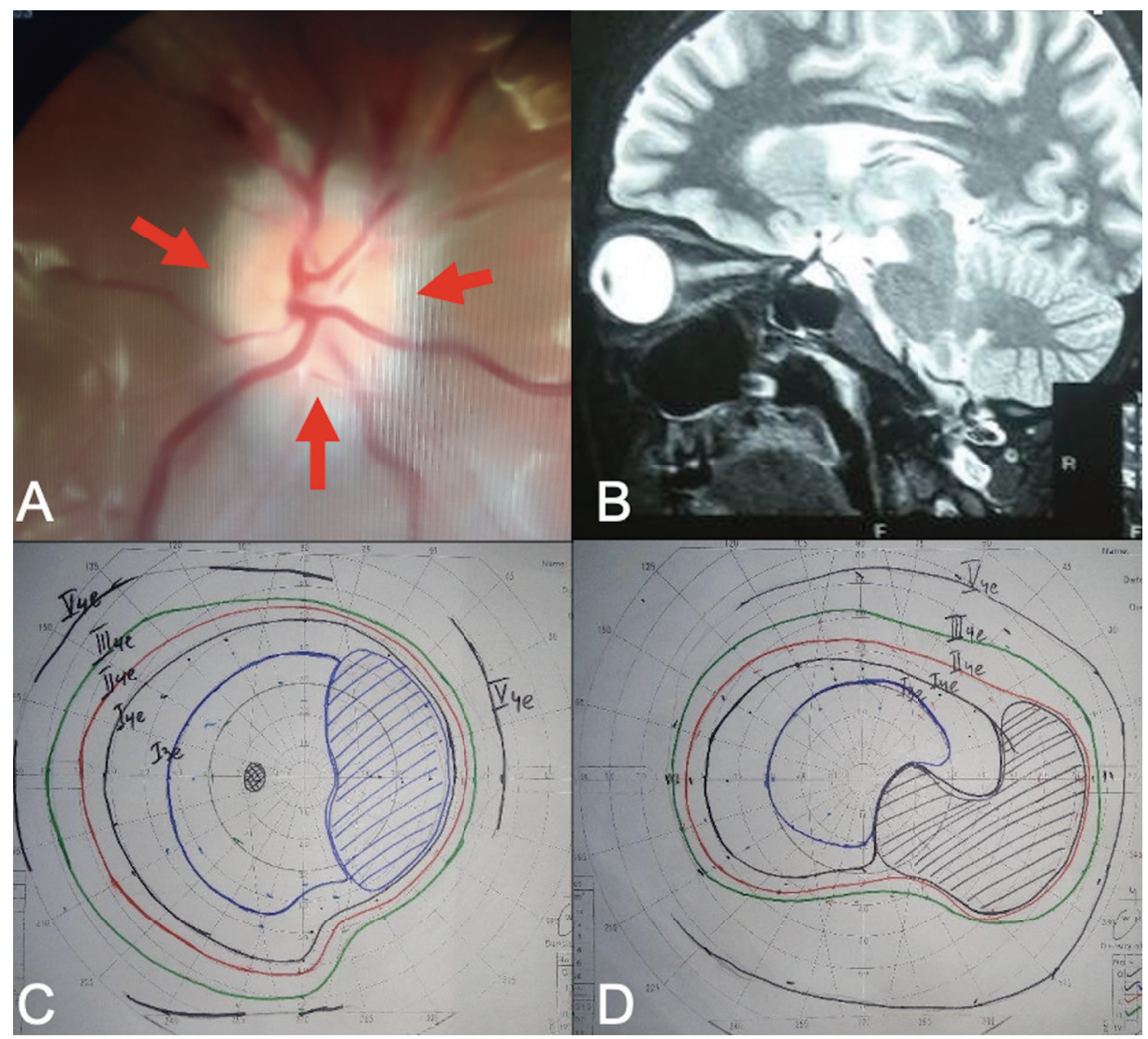

Fig. 1. (A) Hyperaemic right optic disc with undefined margin. (B) Signs of optic neuritis in the right eye with optic nerve enhancement in T2-weighted magnetic resonance image. (C) Goldman kinetic perimetry of the left eye at the 1-week follow-up showing relative paracentral scotoma. (D) Absolute cecocentral scotoma in the right eye.

At the ophthalmological visit, her vision became completely dark. She was in good nutritional status (body mass index: 20) and had no fever. VA at the first visit was no light perception in both eyes, with dilated pupils at $8 \mathrm{~mm}$. The anterior chamber was clear and there were no signs of anterior uveitis. Both optic discs appeared hyperaemic and oedematous (Fig. 1). Colour vision, contrast sensitivity tests, perimetry, and optical coherence tomography (OCT) examinations were not carried out due to the VA conditions at the initial presentation.

Laboratory examination revealed leucopoenia (6.74 [4.5-11.5 103/ $\mu \mathrm{L}])$ and lymphocytosis (52.7 [18-42\%]), suggesting viral infection with positive anti-dengue $\operatorname{lgM}$ and IgG. Other laboratory findings were normal. Magnetic resonance imaging showed bilateral optic nerve oedema strongly suggestive of bilateral optic neuritis 
Table 1. Follow-up conditions after hospital discharge

\begin{tabular}{|c|c|c|c|c|}
\hline & 1 week & 2 weeks & 3 weeks & 4 weeks \\
\hline Right VA & $1 \mathrm{~m} \mathrm{CF}$ & $2 \mathrm{~m} \mathrm{CF}$ & $6 / 15$ & $6 / 6$ \\
\hline Left VA & $2 \mathrm{~m} \mathrm{CF}$ & $6 / 15$ & $6 / 9$ & $6 / 6$ \\
\hline Optic discs & $\begin{array}{l}\text { Hyperaemic at } \\
\text { temporal area }\end{array}$ & $\begin{array}{l}\text { Cup-disc ratio: } \\
0.3 \\
\text { Slightly } \\
\text { hyperaemic }\end{array}$ & $\begin{array}{l}\text { Cup-disc ratio: } \\
0.3 \\
\text { Slightly } \\
\text { hyperaemic }\end{array}$ & $\begin{array}{l}\text { Cup-disc ratio: } \\
0.3 \text { Temporal } \\
\text { pallor }\end{array}$ \\
\hline Perimetry & $\begin{array}{l}\text { OD: absolute } \\
\text { central scotoma } \\
\text { OS: relative } \\
\text { central scotoma }\end{array}$ & $\mathrm{N} / \mathrm{A}$ & $\begin{array}{l}\text { Relative } \\
\text { paracentral } \\
\text { scotoma }\end{array}$ & $\begin{array}{l}\text { Mild peripheral } \\
\text { depression }\end{array}$ \\
\hline $\begin{array}{l}\text { Colour } \\
\text { vision }\end{array}$ & $\begin{array}{l}\text { Dyschroma- } \\
\text { topsia }\end{array}$ & $\begin{array}{l}\text { Dyschroma- } \\
\text { topsia }\end{array}$ & $\begin{array}{l}\text { Dyschroma- } \\
\text { topsia }\end{array}$ & $\begin{array}{l}\text { Dyschroma- } \\
\text { topsia }\end{array}$ \\
\hline $\begin{array}{l}\text { Contrast- } \\
\text { sensitivity }\end{array}$ & $\mathrm{N} / \mathrm{A}$ & $\mathrm{N} / \mathrm{A}$ & $\begin{array}{l}\text { Right eye: } 0.15 \\
\text { Left eye: } 0.75\end{array}$ & Both eyes: 0.6 \\
\hline Laboratory & $\begin{array}{l}\text { Anti-dengue } \\
\text { IgM: negative } \\
\text { Anti-dengue } \\
\text { IgG: positive }\end{array}$ & $\mathrm{N} / \mathrm{A}$ & N/A & $\mathrm{N} / \mathrm{A}$ \\
\hline
\end{tabular}

VA: visual acuity (in Snellen's); CF: counting fingers; N/A: not applicable

(Fig. 1). Pulse steroid therapy (methylprednisolone $1 \mathrm{gr} /$ day) according to the Optic Neuritis Treatment Trial was administered for 3 days.

\section{Follow-up}

Follow-up conditions for weeks 1-4 are described in Table 1. At the 3-month follow-up, best-corrected VA was $6 / 6$, with pale optic discs and normal perimetry. The patient did not complain of any visual symptoms and there were no new neurological complaints. OCT examination results showed retinal nerve fibre layer thinning in both eyes $(46.39 \mu \mathrm{m}$ and $42.54 \mu \mathrm{m}$ in the right and left eye, respectively). Dyschromatopsia was still present in both eyes.

\section{Discussion}

While the pathophysiologic mechanism of optic neuritis after dengue infection is still unclear, it is postulated to be caused by an underlying complex vascular leakage process. ${ }^{2}$ It might be caused by a direct viral infection (infectious neuritis) or by immune-mediated processes after infection. 
Optic neuritis can be an ocular manifestation following dengue fever. ${ }^{3}$ Patients with optic neuritis usually complain of decreased vision, impaired colour perception, relative afferent pupillary defects, and scotoma. The incidence of optic neuritis as a manifestation of dengue fever is usually bilateral, although sometimes patients present with symptoms in only one eye. ${ }^{4}$ Optic neuritis as optic neuromyelitis after dengue fever has been reported with clinical symptoms of acute, unilateral decreased vision and weakness of limbs with Babinski reflex. ${ }^{5}$ Another case report of optic neuritis after dengue virus infection described improvement after intravenous methylprednisolone therapy and physiotherapy. ${ }^{6,7}$

Ocular manifestations due to dengue infection are managed based on clinical presentation, including the provision of anti-inflammatory and immunosuppressive agents. ${ }^{3}$ However, since there have been no prospective, large, and randomized studies to date examining the administration of corticosteroid therapy in optic neuritis due to dengue infection, it is still not clear whether improvement is due to the therapeutic benefits or spontaneous disease resolution.

Ocular complications of dengue fever are rare but may involve severe eye conditions such as optic neuritis, usually occurring in young patients. The pathophysiology and mechanism of occurrence of ocular manifestations in patients with dengue fever are still not fully understood.

\section{Acknowledgments}

Consent to publish the case report was not obtained. This report does not contain any personal information that could lead to the identification of the patient. The authors have no financial disclosures concerning the present report.

\section{References}

1. Bäck AT, Lundkvist A. Dengue viruses - an overview. Infect Ecol Epidemiol. 2013. https// doi.org/10.3402/iee.v3i0.19839. Available at: https://www.ncbi.nlm.nih.gov/pmc/articles/ PMC3759171/

2. Burton EV, Greenberg BM, Frohmann EM. Optic neuritis: a mechanistic view. Pathophysiology. 2011;18(1):81-92. https://doi.org/10.1016/j.pathophys.2010.04.009

3. Ng AW, Teoh SC. Dengue eye disease. Surv Ophthalmol. 2015;60(2):106-114. https://doi. org/10.1016/j.survophthal.2014.07.003

4. Sanjay S, Wagle AM, Au Eong KG. Optic neuropathy associated with dengue fever. Eye (Lond). 2008;22(5):722-724. https://doi.org/10.1038/eye.2008.64

5. Miranda de Sousa A, Puccioni-Sohler M, Dias Borges A, Fernandes Adorno L, Papais Alvarenga M, Papais Alvarenga RM. Post-dengue neuromyelitis optica: case report of a Japanese-descendent Brazilian child. J Infect Chemother. 2006;12(6):396-398. https://doi.org/10.1007/s10156-006-0475-6 
6. Preechawat $P$, Poonyathalag A. Bilateral optic neuritis after dengue viral infection. J Neuroophthalmol. 2005;25(1):51-52. https://doi.org/10.1097/00041327-200503000-00014

7. Aragão RE, Barreira IM, Lima LN, Rabelo LP, Pereira FB. Bilateral optic neuritis after dengue viral infection: case report. Arq Bras Oftalmol. 2010;73(2):175-178. https://doi.org/10.1590/s000427492010000200015 